\title{
Corporate governance practices in private commercial banks-a study on Khulna city
}

\author{
Shanta Kar ${ }^{1}$, Mithun sarker ${ }^{2}$ \\ ${ }^{1}$ Business Administration Discipline Khulna University Khulna-9208, Bangladesh \\ ${ }^{2}$ Pubali Bank, Limited, Dhaka, Bangladesh \\ Email address: \\ Shanta_orchi@yahoo.com (S. Kar), Sarker7777@gmailcom (M. sarker)
}

To cite this article:

Shanta Kar, Mithun sarker. Corporate Governance Practices in Private Commercial Banks-A Study on Khulna City. International Journal of Economic Behavior and Organization. Vol. 2, No. 3, 2014, pp. 37-48. doi: 10.11648/j.ijebo.20140203.12

\begin{abstract}
Corporate governance (CG) is an important effort to ensure accountability and responsibility and is a set of principles, which should be incorporated into every part of the organization. Financial institutions like banks have a significant role to play in the economy of any country. Banking sector should follow the Corporate Governance codes for Bangladesh. So, this paper has tried to evaluate the present scenario of Corporate Governance practices by the private banks in Bangladesh. The study has been conducted to attain some objectives. The primary objective of the study is to evaluate the practices of Corporate Governance codes by the Private Commercial Banks of Bangladesh. In order to do the study, the major issues were focused like rights and disclosure of information, disclosure and transparency, board issues, disclosure and transparency, financial reporting and HRM practices.7 hypotheses have been developed in order to identify whether the private banks are complying corporate governance issues or not. And making the study convenient an assumption was made using subjective probability technique that $70 \%$ or more of private banks of Bangladesh are maintaining $90 \%$ or more CG codes for Bangladesh (Alam, K, 2011). Only 50\% of the major issues like disclosure and transparency, financial reporting and audit practice have met the assumption. Of which $100 \%$ of the CG codes regarding financial reporting are practiced by the $70 \%$ or more private banks and it was $83.33 \%$ for audit practice. In contrast the major issues of CG codes namely shareholders' rights and disclosure of information, board issues and HRM issues are not properly exercised by the private banks. It follows that rights of shareholders are despoiled by the private banks the reason why only $60 \%$ of the issues have been met by $70 \%$ or more private banks. Likewise the board and HRM issues have also failed to meet the assumption. In these two cases the conformance percentages were $60 \%$ and $50 \%$ correspondingly. Consequently the study recommends some approaches that are well thought out for the practice of corporate governance codes by the private commercial banks of Bangladesh.
\end{abstract}

Keywords: Corporate Governance, Hypotheses, Private Banks, Khulna City

\section{Introduction}

\subsection{Background of the Study}

Banks are critically important for industrial expansion, the Corporate Governance (CG) of firms, and capital allocation. When banks efficiently mobilize and allocate funds, this lowers the cost of capital to firms, boosts capital formation, and stimulates productivity growth. Thus, the functioning of banks has ramifications for the operations of firms and the prosperity of nations.

Effective Corporate Governance practices are essential to achieving and maintaining public trust and confidence in the banking system, which are critical to the proper functioning of the banking sector and economy as a whole. As we know banking sector has been performing an essential role in strengthening any economy. Poor Corporate Governance may contribute to bank failures, which can pose significant public costs and consequences due to their potential impact on any applicable deposit insurance systems and the possibility of broader macroeconomic implications, such as contagion risk and impact on payment systems. In addition, poor Corporate Governance can lead markets to lose confidence in the ability of a bank to properly manage its assets and liabilities, including deposits, which could in turn trigger a bank run or liquidity crisis.

The OECD principles define corporate governance as 
involving "a set of relationships between a company's management, its board, its shareholders, and other stakeholders. Corporate governance also provides the structure through which the objectives of the company are set, and the means of attaining those objectives and monitoring performance are determined. Good corporate governance should provide proper incentives for the board and management to pursue objectives that are in the interests of the company and its shareholders and should facilitate effective monitoring. The presence of an effective corporate governance system, within an individual company and across an economy as a whole, helps to provide a degree of confidence that is necessary for the proper functioning of a market economy."

\subsection{Objectives of the Study}

\subsubsection{Primary Objective}

- To evaluate the practices of Corporate Governance codes by the Private Commercial Banks of Bangladesh.

\subsubsection{Secondary Objective}

- Assessing the accountability of private banks of Bangladesh to the stakeholders.

- $\quad$ Evaluating how far the current practice of corporate governance passes the test of fairness in case of private banks.

- To know whether corporate governance system in Bangladesh is transparent for all stakeholders of private banks.

\subsection{Assumption}

[1] An assumption has been taken to conduct the survey that $70 \%$ or more of the banks in Bangladesh are satisfying with $90 \%$ or more issues of the corporate governance codes. Conformity of corporate governance codes for each issue is determined when $70 \%$ or more banks have satisfied with that assumption. The probability has been taken based on subjective probability technique. (Douglas A. Lind, William G. Marchal, "Statistical Techniques in Business and Economics", Fourteenth Edition, pp. 146-147)

\subsection{Questions for Hypothesis}

1. Is it reasonable to infer that the requirements of Shareholders' Rights and Disclosure of Information are meeting the corporate governance codes?

2. Is it reasonable to conclude that the provisions for Disclosure and Transparency are meeting the corporate governance codes?

3. Is it reasonable to deduce that the rudiments on Board of Directors issues are meeting the corporate governance codes?

4. Is it reasonable to infer that the policies for Financial Reporting are meeting the corporate governance codes?

5. Is it reasonable to deduce that the regulations of Audit practiced by the banks are meeting the corporate governance codes?

6. Is it reasonable to conclude that the HRM policies adopted by the banks are meeting the corporate governance codes?

7. Is it reasonable to conclude that the corporate governance codes are practiced as per the assumption?

\subsection{Hypothesis Development}

Hypothesis-1

$H_{0}$ : The state of affairs of Shareholder Rights and Disclosure of Information is being met the corporate governance codes by the private banks.

$H_{A}$ : The state of affairs of Shareholder Rights and Disclosure of Information is not being met the corporate governance codes by the private banks.

Hypothesis-2

$H_{0}$ : The state of affairs for Disclosure and Transparency is being met the CG corporate governance codes by the private banks.

$H_{A}$ : The state of affairs for Disclosure and Transparency is not being met the corporate governance codes by the private banks.

Hypothesis-3

$H_{0}$ : The state of affairs of Board of Directors issues is being met the corporate governance codes by the private banks.

$H_{A}$ : The state of affairs of Board of Directors issues is not being met the corporate governance codes by the private banks.

Hypothesis-4

$H_{0}$ : The state of affairs of Financial Reporting is being met the corporate governance codes by the private banks.

$H_{A}$ : The state of affairs of Financial Reporting is not being met the corporate governance codes by the private banks.

Hypothesis-5

$H_{0}$ : The state of affairs of Audit practiced by the private banks is meeting the corporate governance codes.

$H_{A}$ : The state of affairs of Audit practiced by the private banks is not meeting the corporate governance codes.

Hypothesis-6

$H_{0}$ : The state of affairs of HRM policies adopted by the banks is meeting the corporate governance codes.

$H_{A}$ : The state of affairs of HRM policies adopted by the banks is not meeting the corporate governance codes.

Hypothesis-7

$H_{0}$ : The corporate governance codes are practiced by the private banks as per the assumption.

$H_{A}$ : The corporate governance codes are not practiced by the private banks as per the assumption. 


\subsection{Scope of the Study}

The primary scope of the study is the operating private banks in Khulna city and the executives and experts of banks.

\subsection{Methodology Applied}

The following are the bases that have been followed to conduct the study. As it is a descriptive research, Survey technique has been used to conduct the study.

\subsection{Data Collection}

\subsubsection{Primary Source}

Primary data have been collected through conducting survey.

\subsubsection{Secondary Source}

Secondary data have been collected from different journals, books, banks' websites and banks' annual report.

\subsection{Target Population}

The target populations of this study are the managers, executives and shareholders of different private operating banks in Khulna city.

\subsection{Sampling Method}

Non Probability sampling technique was used as a sampling method. Under which convenient technique has been used to gather primary data. And sample size has been determined 10 scheduled private banks those have branches in Khulna city.

\subsection{Questionnaire Development}

The questionnaire consists of both open and close ended questions. The questionnaire has been developed based on the corporate governance codes for Bangladesh.

\subsection{Research Method}

To do this study a questionnaire has been developed to collect information about corporate governance practiced by the sample banks. The questionnaire has been divided into different sections such as company profile, shareholders' rights and disclosure, public disclosure and transparency, effectiveness of the board, function of the board, and effectiveness of the independent directors. The questionnaire was made semi-structured to allow for indepth interviews with key individuals of the companies.

\subsection{Measuring Instruments}

Scales Include 5 point Likert scales. Where $5=$ strongly agree, 4=Agree, 3=No opinion, 2=Disagree, 1= strongly disagree

\subsection{Data Analysis Method}

In this step, each element of the major issues of corporate governance has been tabulated and analyzed. For some analysis here, percentage system has been used. It has been presented in terms of tables, figures, and graphs as well as written scripts. For the processing and analyzing numerical data, means, standard deviations and $\mathrm{z}$ tests (Gupta and Gupta, 2006-2007) have been used in the study.

\subsection{Limitations Faced}

The major limitation of the study was short time. In addition some banks had not adequate information on different issues not only that but also some respondents did not disclose all the information especially in financial reporting and audit practices, even after giving the assurance that the result would be used for study purpose and published in aggregate manner. Moreover some terminologies were not familiar to some respondents then it needed to make the respondent understand first which took longer.

\section{Literature Review}

\subsection{What is Corporate Governance?}

Different authors view the meaning of corporate governance differently. For example, one school of thoughts describes corporate governance as a "system" by which companies are directed and controlled (Cadbury and Greenbury Report, 1992). But it must be kept in our mind that the fundamental concern of corporate governance is to ensure the conditions whereby a firm's directors and mangers are held accountable, ensure better and effective protection to all stakeholders. The World Bank argues that the framework of corporate governance should be based on four pillars such as Responsibility, Accountability, Fairness and Transparency (RAFT).

According to Kocourek, P. F, (2003), to counter the accounting, leadership, and governance scandals, organizations are rushing to institutionalize corporate governance, which may be even be counterproductive. The drive to more tightly regulate the membership and functions of corporate boards is already encouraging companies to view governance as a legal challenge rather than a way to improve performance.

There is no universally accepted code that ensures good corporate governance. But there are some variables on which the corporate governance framework established. Those are Responsibility, Accountability, Fairness and Transparency.

\subsection{Corporate Governance Scenario in Bangladesh}

Corporate governance practices in Bangladesh are quite absent in most companies and organizations. In fact, Bangladesh has lagged behind its neighbors and the global economy in corporate governance. One reason for this absence of Corporate Governance is that most companies are family oriented. Moreover, motivation to disclose information and improve governance practices by companies is felt negatively. There is neither any value judgment nor any consequences for corporate governance practices. The current system in Bangladesh does not provide sufficient legal, institutional and economic 
motivation for stakeholders to encourage and enforce corporate governance practices; hence failure in most of the constituents of corporate governance is witness in Bangladesh. Some of the individual constituents that have been identified by MamtazUddin Ahmed and Mohammad Abu Yusuf in their research study "Corporate Governance: Bangladesh Perspective” (Mamtaz and Yusuf, 2005) are:

- Poor bankruptcy laws

- No push from the international investor community

- Limited or no disclosure regarding related party transactions

- Weak regulatory system

- General meeting scenario

- Lack of shareholder active participations

\subsection{Corporate Governance Guidelines for Banking Sector}

Given the important financial intermediation role of banks in an economy, their high degree of sensitivity to potential difficulties arising from ineffective corporate governance and the need to safeguard depositors' funds, corporate governance for banking organizations is of great importance to the international financial system and merits targeted supervisory guidance. The Basel Committee on Banking Supervision published guidance in 1999 to assist banking supervisors in promoting the adoption of sound corporate governance practices by banking organizations in their countries. This guidance drew from principles of corporate governance that were published earlier that year by the Organization for Economic Co-operation and Development (OECD) with the purpose of assisting governments in their efforts to evaluate and improve their frameworks for corporate governance and to provide guidance for financial market regulators and participants in financial markets.

Banking companies pose unique corporate governance attention as they differ greatly with other types of firms in terms of broader extent of claimants on the banks assets and funds. A group of entrepreneurs and/or executives could set up a banking business by putting very little equity from their own pocket as the nature of business itself guarantees flow of enormous amount of funds in the form of deposits. The general approach to corporate governance argue in favor of the shareholders rights only, as managers/executives may not always work in the best interest of the shareholders (Jensen, M.C. and Meckling, W.H. (1976), Fama,E. and M. Jensen (1983), But the shareholders actually account for a very tiny portion of the bank's assets and funds. Rather almost every bit of banks' investments are financed by the depositors' funds. In case of losses or failures it will be depositors' savings that the banks would lose. Such risks demand priority in protection of depositors that ushers in a broader view of corporate governance that suggests the interest and benefits of the suppliers of funds for a firm should be. The self-dealing activities by the bank insiders are very dangerous to the performance and survival of the banks as scores of previous bank failures have been caused by risky self-dealing by the bank insiders (Clarke, 1988). The presence of heavy liquid assets and potential lack of depositors' interest to actively control and monitor banks' risky decisions as a result of the insurance guarantees simplifies and aggravates the sharking in the banking firms.

Banks in developing countries are faced with high risk of sharking as a result of heavy government ownership, lack of prudential regulation, weak legal protection and presence of special interest groups (Arun, T.G. and J. Turner (2003), However, there is an argument that active role by regulators may cause problems as well, as regulators may not have a convincing or sufficient motivation to monitor the banks as they do not have much at stake in case of bank failures. Recently, the financial markets of developing economies have experienced rapid changes due to the growth of wider range of financial products. As a result of this, banks have been involved with high risk activities such as trading in financial markets and different offbalance sheet activities more than ever before (Greuning, $\mathrm{H}$. and S. Bratanovic (2003), ) which necessitate an added emphasis on quality of corporate governance of banks in developing economies.

Asian Roundtable on Corporate Governance (ARCG) Task force developed the Policy Brief on Corporate Governance of Banks in Asia (June 2006). The main issues and priorities for reforms in CG of banks in Asia that were identified are:

- The responsibility of individual board membersfiduciary duties of bank' board members, need of skills, personal abilities, training programs on integrity and professionalism.

- The roles or functions of the board-guiding, approving and overseeing strategies or policies rather than being immersed in day-to-day operations. Creating clear accountability lines and internal control systems. Sufficient flows of information and managerial support.

- The composition of the board-banks is more encouraged to have independent directors than other firms. Separation between Chairman and CEO.

- The committees of the board-audit committee, the Risk Management Committee, The Governance Committee with combined responsibilities of Nomination, remuneration, succession planning, training, performance evaluation, etc.

- Preventing abusive related party transactionsinspection of the existing firewall. Creation of specialized committee to monitor and approve related part transaction. Publicly disclose such transaction.

- $\quad$ Bank holding companies and groups of companies holding banks-a bank's parent company should not impede the full exercise of the CG of the bank within the banking group.

- Disclosure-effort on convergence into international 
standards on accounting, etc. should be encouraged.

- Bank's autonomy in relation to the state-state as owner should respect the legal corporate structures of State Owned Commercial Banks

- Bank's monitoring of the CG structure of its corporate borrowers-Extent to which banks should assess or monitor $\mathrm{CG}$ of their corporate borrowers or seek to improve it.

Actually the principle legal instrument for enforcing governance in Bangladesh is the Companies Act 1994 which is administered by Registrar of Joint Stock Company (RJSC) and the Ministry of Commerce. SEC is concerned with publicly limited companies only, the number of which is very insignificant. Close monitoring of leading companies is a disincentive for going public as there is a perception that this will create and raise unnecessary difficulties for companies to supply information as and when requested.

\section{Analysis and Interpretation}

\subsection{Shareholders' Rights and Disclosure of Information}

On the issue of shareholders' rights and disclosure, the study investigated several key issues: i) the practice of voting in the Annual General Meeting of the companies, ii) disclosure of information in terms of knowing the agenda, iii) lead time to analyze information, iv) information on equity of major shareholders, v) practice of nomination and disclosure of director candidates in the meeting, vi) rights of the minority shareholders in nominating candidates. To understand shareholders' rights the study used several proxy variables like a) length of the meeting, and b) attendance in the meetings. Duration of the meetings indicates whether shareholders' are given opportunities to debate on issues related to their interest or not. Similarly, higher attendance of the meeting indicates presence of a pluralistic environment in the decision making process. It was found that duration of the AGMs in these companies were mostly between 2-3 hours.

\subsubsection{Ease of Participation in Voting by Shareholders}

The following Pie chart illustrates that in terms of ease of participating in the meetings, shareholders used several options to express their opinion. Most of the shareholders participate in voting bodily.

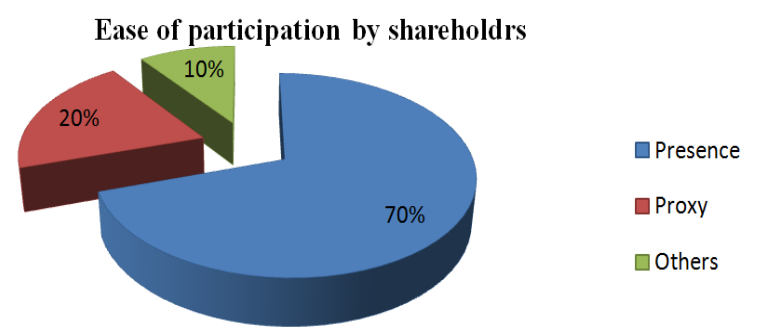

Figure 1. Ease of Participation in Voting by Shareholders.
The resulting data with conformity and non conformity level on this issue is given in the following graph.

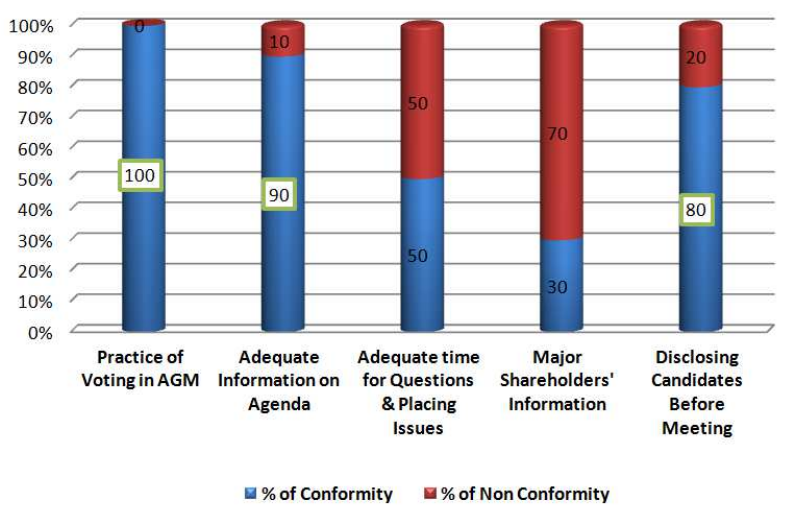

Number in box indicates conformed attributes

Graph 1. Shareholders' Rights and Disclosure of Information.

Hypothesis Test-1

$H_{0}$ : The state of affairs of Shareholder Rights and

Disclosure of Information is meeting the CG codes in the private banks.

$H_{A}$ : The state of affairs of Shareholder Rights and Disclosure of Information is not meeting the CG codes in the private banks.

Here,

Total attributes, $n=5$

Total conformed attributes, $x=3$

Conformance probability in the population, $\mathrm{p}=0.90$

Non conformance probability in the population, $q=0.10$

Thus attributes' population mean $(\mu)=n \times p=n p=$ $5 \times 0.90=4.5$

Standard deviation, $(\sigma)=\sqrt{n p q}=\sqrt{4.5 \times 0.10}=0.67$

Calculated $z$ value: $z=\frac{x-n p}{\sigma}=\frac{3-4.5}{0.67}=-2.24$

Significance level $=5 \%$

0.50 0.50

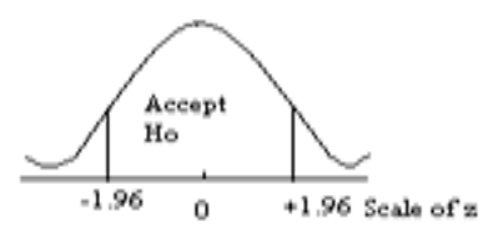

A two tailed test

$$
\frac{\alpha}{2}=\frac{0.05}{2}=0.025
$$

Table value of $z= \pm 1.96$. It is the corresponding value of $0.475=(0.5-.025)$

Here, Reject ${ }^{H_{0}}$, So, it can be concluded that the CG codes on Shareholders' Rights and Disclosure of Information are not maintained properly by the $70 \%$ or more private banks of Bangladesh. 


\subsection{Disclosure and Transparency}

The resulting data with conformity and non conformity level on this issue is given in the following graph.

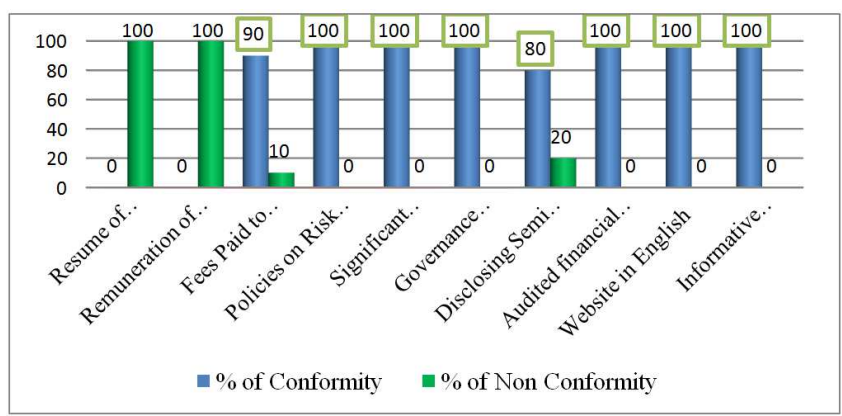

Number in box indicates conformed attributes

Graph 2. Disclosure and Transparency.

Hypothesis Test-2

$H_{0}$ : The state of affairs for Disclosure and Transparency is being met the CG codes by the private banks.

$H_{A}$ : The state of affairs for Disclosure and Transparency is not being met the $\mathrm{CG}$ codes by the private banks.

Here,

Total attributes, $n=10$

Total satisfying attributes, $x=8$

Conformance probability in the population, $\mathrm{p}=0.90$

Non conformance probability in the population, $q=0.10$

Thus attributes' population mean $(\mu)=n \times p=n p=$ $10 \times 0.90=9$

Standard deviation, $(\sigma)=\sqrt{n p q}=\sqrt{9 \times 0.10}=0.95$

Calculated $z$ value: $z=\frac{x-n p}{\sigma}=\frac{8-9}{0.95}=-1.054$

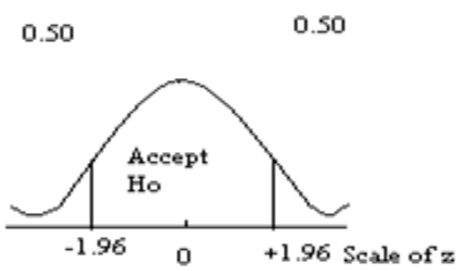

Significance level $=5 \%$

A two tailed test

$$
\frac{\alpha}{2}=\frac{0.05}{2}=0.025
$$

Table value ofz $= \pm 1.96$.It is the corresponding value of $0.475=(0.5-.025)$

Here,

Do not reject $H_{0}$. So, it can be concluded that the CG codes of disclosure and transparency are maintained by the $70 \%$ or more private banks of Bangladesh.

\subsection{Board Issues}

The board issues are summarized in the following graph.

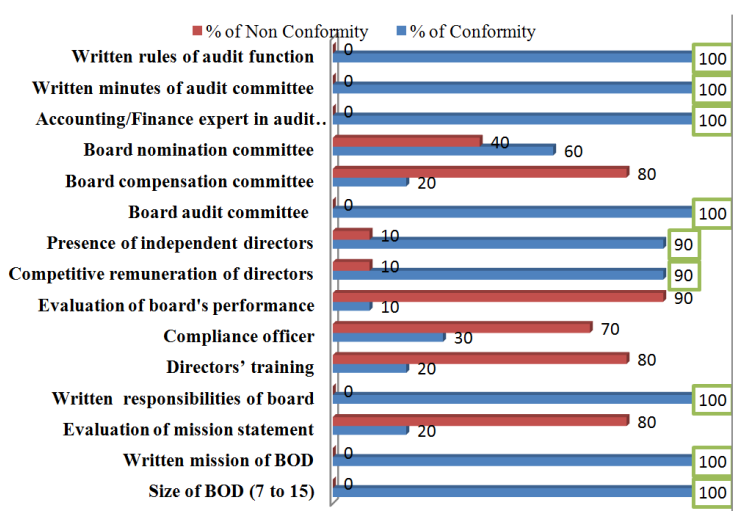

Number in box indicates conformed attributes

Graph 3. Board Issues.

Hypothesis Test-3

$H_{0}$ : The state of affairs of Board of Directors issues is being met the $\mathrm{CG}$ codes by the private banks.

$H_{A}$ : The state of affairs of Board of Directors issues is not being met the $\mathrm{CG}$ codes by the private banks.

Here,

Total attributes, $\mathrm{n}=15$

Total conformed attributes, $\mathrm{x}=9$

Conformance probability in the population, $p=0.90$

Non conformance probability in the population, $\mathrm{q}=0.10$

So, attributes' populations mean $(\mu)=\mathrm{n} \times \mathrm{p}=\mathrm{np}=$ $15 \times 0.90=13.5$

Standard deviation, $(\sigma)=\sqrt{\mathrm{npq}}=\sqrt{13.5 \times 0.10}=$ 1.16

Calculated $\mathrm{z}$ value: $\mathrm{z}=\frac{\mathrm{x}-\mathrm{np}}{\sigma}=\frac{9-13.5}{1.16}=-3.873$

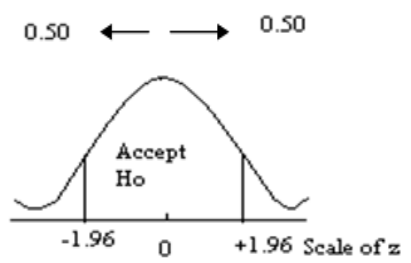

Significance level $=5 \%$

A two tailed test

$$
\frac{\alpha}{2}=\frac{0.05}{2}=0.025
$$

Table value ofz $= \pm 1.96$.It is the corresponding value of $0.475=(0.5-.025)$.

Here, Reject, $H_{0}$.So, it can be concluded that the CG codes on board issues are not practiced as we were expecting by the $70 \%$ or more private banks of Bangladesh.

\subsection{Financial Reporting}

From the survey apparently it implies that most of the private banks of Bangladesh follow either Bangladesh Accounting Standards (BAS) or International Accounting Standards. Not only that but also most of the banks believe that the accounts show a fair picture. Moreover the 
experience and qualification of CFO are strictly maintained by all the banks.

Summary of financial reporting: Assembling the data in the following graph.

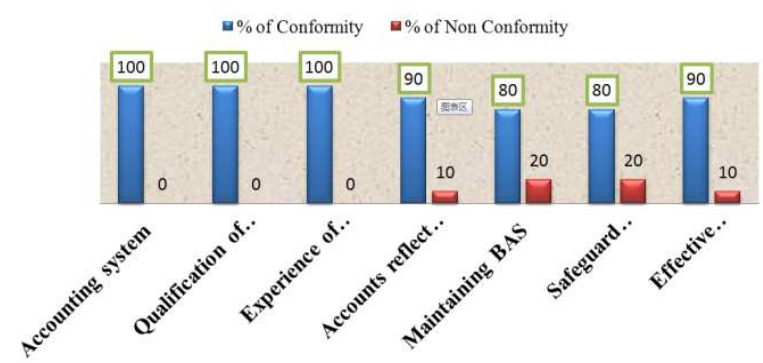

Number in box indicates conformed attributes

Graph 4. Financial Reporting.

Hypothesis Test-4

$H_{0}$ : The state of affairs of Financial Reporting is being met the CG codes by the private banks.

$H_{A}$ : The state of affairs of Financial Reporting is not being met the CG codes by the private banks.

Here,

Total attributes, $n=7$

Total conformed attributes, $x=7$

Conformance probability in the population, $p=0.90$

Non conformance probability in the population, $\mathrm{q}=0.10$

Thus attributes' populations mean $(\mu)=n \times p=n p=$ $7 \times 0.90=6.3$

Standard deviation, $(\sigma)=\sqrt{n p q}=\sqrt{6.3 \times 0.10}=0.79$

Calculated $\mathrm{z}$ value: $z=\frac{\mathrm{x}-\mathrm{np}}{\sigma}=\frac{7-6.3}{0.79}=+0.89$

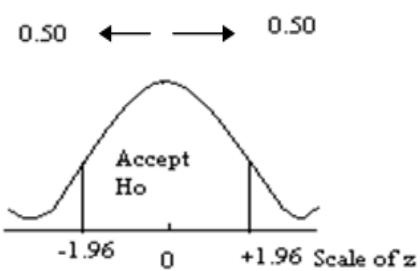

Significance level $=5 \%$

A two tailed test

$$
\frac{\alpha}{2}=\frac{0.05}{2}=0.025
$$

Table value ofz $= \pm 1.96$.It is the corresponding value of $0.475=(0.5-.025)$

Here,

Do not reject $H_{0}$. So, it can be concluded that all the CG codes on financial reporting are practiced by the $70 \%$ or more private banks of Bangladesh.

\subsection{Audit Practices}

Most of the issues of audit practice under the CG codes of Bangladesh are implemented by the private banks. All the banks audit their accounts by internal and external auditors.

\subsubsection{Summary of Audit Practice}

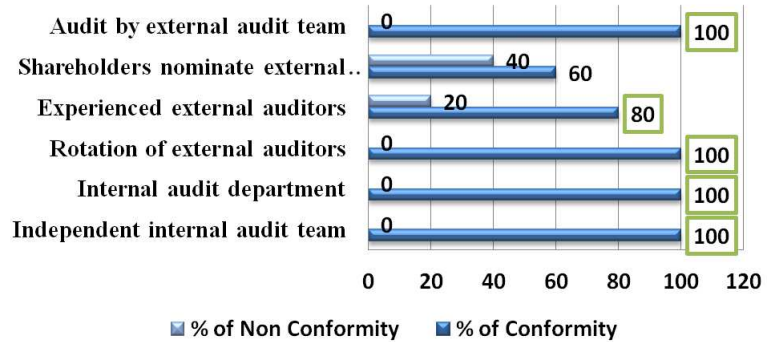

Number in box indicates conformed attributes

Graph 5. Audit Practice.

Hypothesis Test-5

$H_{0}$ : The state of affairs of Audit practiced by the private banks is meeting the $\mathrm{CG}$ codes.

$H_{A}$ : The state of affairs of Audit practiced by the private banks is not meeting the CG codes.

Here,

Total attributes, $n=6$

Total conformed attributes, $x=5$

Conformance probability in the population, $\mathrm{p}=0.90$

Non conformance probability in the population, $q=0.10$

Thus attributes' populations mean $(\mu)=n \times p=n p=$ $6 \times 0.90=5.4$

Standard deviation, $(\sigma)=\sqrt{n p q}=\sqrt{5.4 \times 0.10}=0.73$

Calculated $\mathrm{z}$ value: $z=\frac{\mathrm{x}-\mathrm{np}}{\sigma}=\frac{5-5.4}{0.73}=-0.54$

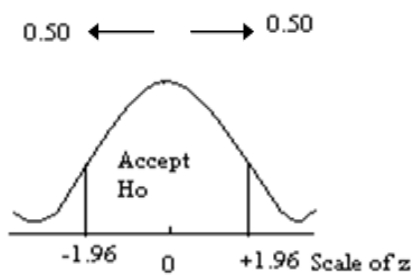

Significance level $=5 \%$

A two tailed test

$$
\frac{\alpha}{2}=\frac{0.05}{2}=0.025
$$

Table value ofz $= \pm 1.96$.It is the corresponding value of $0.475=(0.5-.025)$

Here, Do not reject $H_{0}$. So, it can be concluded that the CG codes on audit practice are practiced by the $70 \%$ or more private banks of Bangladesh.

\subsection{Human Resources Management}

The HRM practice by the private banks of Bangladesh is not up to that mark. The study reveals that the average HRM practice fails to meet the assumption. Though most of the private banks have problem solving groups, self- 
directed teams and profit sharing practice but other issues regarding HRM are not accepted level, such as, only $30 \%$ of surveyed banks have cross training system which is the most efficient tool to improve the proficiency of employees. Moreover there is no such private bank that uses employee stock ownership plan.

\subsubsection{Summary of HRM Practice}

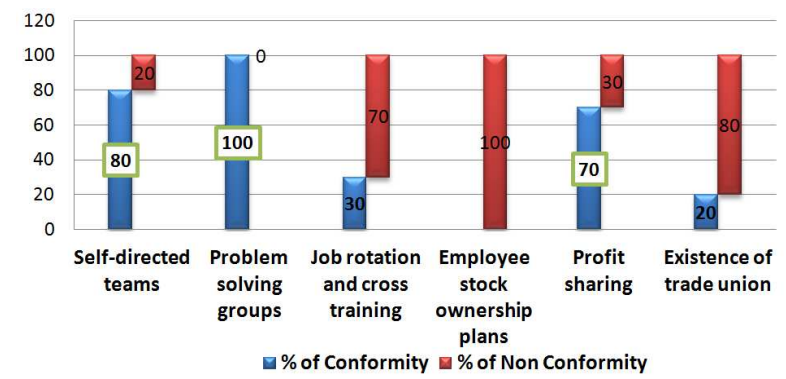

Number in box indicates conformed attributes

Graph 6. Human Resource Management.

Hypothesis Test-6

$H_{0}$ : The state of affairs of HRM policies adopted by the banks is meeting the $\mathrm{CG}$ codes.

$H_{A}$ : The state of affairs of HRM policies adopted by the banks is not meeting the CG codes.

Here,

Total attributes, $n=6$

Total conformed attributes, $x=3$

Conformance probability in the population, $\mathrm{p}=0.90$

Non conformance probability in the population, $q=0.10$

Thus attributes' populations mean $(\mu)=n \times p=n p=$ $6 \times 0.90=5.4$

Standard deviation, $(\sigma)=\sqrt{n p q}=\sqrt{5.4 \times 0.10}=0.73$

Calculated $z$ value: $z=\frac{x-n p}{\sigma}=\frac{3-5.4}{0.73}=-3.27$

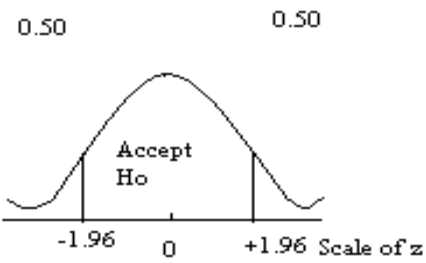

Significance level $=5 \%$

A two tailed test

$$
\frac{\alpha}{2}=\frac{0.05}{2}=0.025
$$

Table value ofz $= \pm 1.96$.It is the corresponding value of $0.475=(0.5-.025)$

Here, Reject $H_{0}$.So, it can be concluded that the CG codes on human resource management are not practiced according to the expectation by the $70 \%$ or more private banks of Bangladesh.

\subsection{Summary of the Hypotheses}

There are seven broad issues in CG codes for banks. And those issues cover several important aspects which are the yardstick or guidelines for the banks. This study has tried to reveal the actual scenario of $\mathrm{CG}$ practice by the private banks based on an assumption. Only 50\% of major CG codes have been accepted by doing hypothesis test.

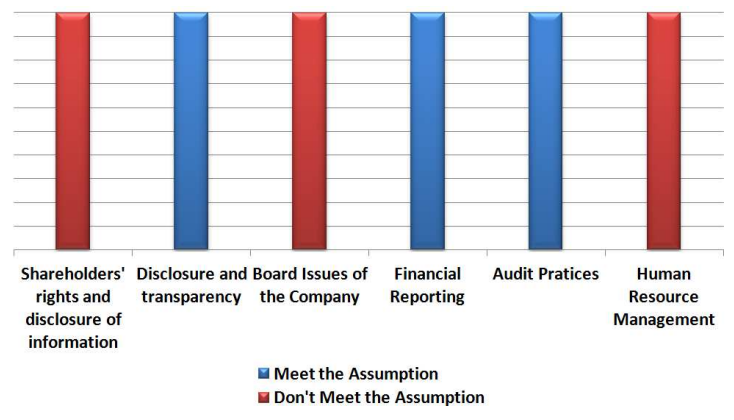

Graph 7. Hypotheses Result.

Hypothesis Test-7

$H_{0}$ : The CG codes are practiced by the private banks as per the assumption.

$H_{A}$ : The CG codes are not practiced by the private banks as per the assumption.

Here,

Total issues, $n=6$

Issues that meet the assumption, $x=3$

Assumed probability of conform in the population, $\mathrm{p}=0$. 90

Non conformance probability in the population, $\mathrm{q}=0.10$

Thus attributes' populations mean $(\mu)=n \times p=n p=$ $6 \times 0.90=5.4$

Standard deviation, $(\sigma)=\sqrt{n p q}=\sqrt{5.4 \times 0.10}=0.73$

Calculated $\mathrm{z}$ value: $z=\frac{\mathrm{x}-\mathrm{np}}{\sigma}=\frac{3-5.4}{0.73}=-3.29$

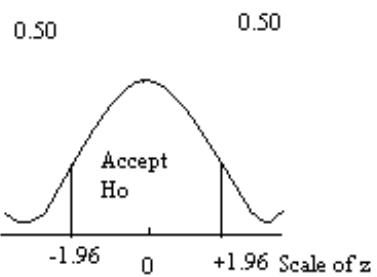

Significance level $=5 \%$

A two tailed test

$$
\frac{\alpha}{2}=\frac{0.05}{2}=0.025
$$

Table value ofz $= \pm 1.96$.It is the corresponding value of $0.475=(0.5-.025)$

Here,

Reject $H_{0}$. So, it can be concluded that the CG codes are not practiced according to the expectation by the $70 \%$ or more private banks of Bangladesh. 


\section{Findings}

\subsection{Shareholders' Rights and Disclosure of Information}

The CG codes on Shareholders' Rights and Disclosure of Information are not practiced by the $70 \%$ or more private banks of Bangladesh. This is one of the major issues to ensure good governance in banking sector.

\subsection{Disclosure and Transparency}

The hypothesis result shows that the CG codes of disclosure and transparency are maintained by the $70 \%$ or more private banks of Bangladesh. In this issue it has been found that the directors' information is not disclosed properly.

\subsection{Board Issues}

One of the important issues of the CG codes, is board issue that has not been practiced according to the assumption. Only $63.63 \%$ of the board issues are complied by $70 \%$ or more private banks.

\subsection{Financial Reporting}

From the analysis it is clear that $100 \%$ issues of financial reporting are complied by the $70 \%$ or more banks. That is very essential for ensuring good governance.

\subsection{Audit Practice}

From the analysis part it can be inferred that the CG codes of audit practice issues are practiced by the $70 \%$ or more private banks.

\subsection{Human Resource Management}

In this important issue the scenario is not satisfactory level. Only $50 \%$ of the HRM issues are practiced by the $70 \%$ or more private banks.

\subsection{Summary of the Hypotheses}

In this case the null hypothesis is rejected which indicates the CG codes are not practiced by the $70 \%$ or more private banks

\section{Conclusion and Recommendation}

\subsection{Conclusion}

The primary objective of the study was to evaluate the practices of Corporate Governance codes by the Private Commercial Banks of Bangladesh. The broad issues like shareholders' rights and disclosure of information, disclosure and transparency, financial reporting, audit practices, board issues and HRM practice are the main yardstick to assess the practice of CG codes. In order to conduct the research a questionnaire was developed based on $\mathrm{CG}$ codes for Bangladesh. And the questionnaire was surveyed on ten sample private banks to gather primary data. Not only that but also different experts, executives were interviewed to appear at the following conclusion.

It has been found from the research that the scenario of practicing the $\mathrm{CG}$ codes by the private banks of Bangladesh has no4=U74 met the assumption. Only $50 \%$ of the major issues like disclosure and transparency, financial reporting and audit practice have met the assumption. Of which $100 \%$ of the $\mathrm{CG}$ codes regarding financial reporting are practiced by the $70 \%$ or more private banks and it was $83.33 \%$ for audit practice. In contrast the major issues of CG codes namely shareholders' rights and disclosure of information, board issues and HRM issues are not properly exercised by the private banks. It follows that rights of shareholders are despoiled by the private banks the reason why only $60 \%$ of the issues have been met by $70 \%$ or more private banks. Likewise the board and HRM issues have also failed to meet the assumption. In these two cases the conformance percentages were $60 \%$ and $50 \%$ correspondingly. In short the fairness, accountability and transparency of private banks are not at satisfactory level.

The banking sector of Bangladesh is becoming stronger day by day and it is playing a pivotal role in the volatile economy of this country to become Bangladesh one of the growing economies of the world in near future. So to be more effective and to put more contribution for the betterment of Bangladesh, the banking sector should follow the CG codes properly to bring the authenticity in its operations and to bring the faith of the stakeholders as well as the people of Bangladesh.

\subsection{Recommendation}

After completing the research following recommendations have been made to ensure the practice of corporate governance codes in private banks and to improve the banking sector of Bangladesh.

- Vision and mission should clearly be stated and should be evaluated intermittently.

- Job rotation and cross training should be introduced in every organization.

- The effectiveness of independent directors should be increased in the organization to bring the transparency.

- The performance of Board of directors should be evaluated timely to bring the accountability in the organization.

- The members of Board of directors should be provided training to make them efficient in their duties.

- The information on major shareholders' equity and ownership should be disclosed.

- Adequate time and scope should be given to the shareholders for asking questions and placing issues in the Annual General Meeting (AGM).

- $\quad$ Resume of directors of every organization should be disclosed. 


\section{Appendix: Analysis Table}

Table 1. Shareholders Rights and Disclosure of Information.

\begin{tabular}{lllll}
\hline \multirow{2}{*}{ CG Code } & \multicolumn{2}{l}{ Conform with CG codes } & \multicolumn{2}{l}{ Not conform with CG codes } \\
\cline { 2 - 5 } & Yes & \% of Respondents & No & \% of Respondents \\
\hline Practice of Voting in AGM & 10 & 100 & 1 & 10 \\
Adequate Information on Agenda & 9 & 90 & 5 & 50 \\
Adequate time for Questions \& Placing Issues & 5 & 50 & 7 & 70 \\
Major Shareholders' Information & 3 & 30 & 2 & 20 \\
Disclosing Candidates Before Meeting & 8 & 80 & & \\
\hline
\end{tabular}

Bold color indicates the code meets the assumption.

Table 2. Disclosure and Transparency.

\begin{tabular}{lllll}
\hline \multirow{2}{*}{ CG code } & \multicolumn{2}{l}{ Conform with CG codes } & Not conform with CG codes \\
\cline { 2 - 5 } & Yes & \% of Respondents & No & \% of Respondents \\
\hline Resume of Directors & & & 10 & 100 \\
Remuneration of Directors & 90 & 90 & 10 & 100 \\
Fees Paid to External Auditors & 10 & 100 & 1 & 10 \\
Policies on Risk Management & 10 & 100 & & \\
Significant Changes in Ownership & 10 & 100 & & 20 \\
Governance structures and polices & 8 & 80 & 2 & \\
Disclosing Semi Annual Report & 10 & 100 & & \\
Audited financial statement & 10 & 100 & & \\
Website in English & 10 & 100 & & \\
Informative Website & & &
\end{tabular}

Bold color indicates the code meets the assumption.

Table 3. Board Issues.

\begin{tabular}{lllll}
\hline \multirow{2}{*}{ CG code } & \multicolumn{2}{l}{ Conform with CG codes } & \multicolumn{2}{l}{ Not conform with CG codes } \\
\cline { 2 - 4 } & Yes & \% of Respondents & No & \% of Respondents \\
\hline Written mission of BOD & 10 & 100 & 8 & 80 \\
Evaluation of mission statement & 2 & 20 & & 80 \\
Written responsibilities of board & 10 & 100 & 8 & 70 \\
Directors' training & 2 & 20 & 7 & 90 \\
Compliance officer & 3 & 30 & 9 & 90 \\
Evaluation of board's performance & 1 & 10 & 1 & 10 \\
Remuneration of directors & 1 & 10 & & 80 \\
Presence of independent directors & 9 & 90 & 4 & 40 \\
Board audit committee & 10 & 100 & & \\
Board compensation committee & 2 & 20 & & \\
Board nomination committee & 6 & 60 & & \\
Accounting/Finance expert in audit committee & 10 & 100 & & \\
Written minutes of audit committee & 10 & 100 & & \\
Written rules of audit function & 10 & 100 & & \\
Size of BOD (7 to 15) & 10 & 100 & & \\
\hline
\end{tabular}

Bold color indicates the code meets the assumption.

Table 4. Financial Reporting.

\begin{tabular}{lllll}
\hline \multirow{2}{*}{ CG code } & \multicolumn{2}{l}{ Conform with CG codes } & Not conform with CG codes \\
\cline { 2 - 5 } & Yes & \% of Respondents & No & \% of Respondents \\
\hline Accounting system & 10 & 100 & 0 & 0 \\
Qualification of CFO & 10 & 100 & & \\
Experience of CFO & 10 & 100 & 1 & 10 \\
Accounts reflect a fair picture** & 9 & 90 & 2 & 20 \\
Maintaining BAS** & 8 & 80 & 2 & 20 \\
Safeguard against unethical behavior** & 8 & 80 & 1 & 10 \\
Effective internal audit** & 9 & 90 & & \\
\hline
\end{tabular}

Bold color indicates the code meets the assumption. 
Table 4.1 Financial Reporting.

\begin{tabular}{llllll}
\hline Opinion & Strongly Agree & Agree & No opinion & Disagree & Strongly disagree \\
Attributes & 9 & 1 & & \\
\hline Accounts reflect a fair picture & 8 & 1 & 1 & \\
Maintaining BAS & 2 & & \\
Safeguard against unethical behavior & 8 & 1 & & \\
Effective internal audit & 9 & 2 & & \\
\hline
\end{tabular}

**The attribute meets the CG codes when answers are Strongly Agree.

Table 5. Audit Practices.

\begin{tabular}{lllll}
\hline \multirow{2}{*}{ CG code } & \multicolumn{2}{l}{ Conform with CG codes } & Not conform with CG codes \\
\cline { 2 - 4 } & Yes & \% of Respondents & No & \% of Respondents \\
\hline Audit by external audit team & 10 & 100 & 4 & 40 \\
Shareholders nominate external auditor & 6 & 60 & 2 & 20 \\
Experienced external auditors & 8 & 80 & & \\
Rotation of external auditors & 10 & 100 & & \\
Internal audit department & 10 & 100 & 100 & \\
Independent internal audit team & 10 & 100 & \\
\hline
\end{tabular}

Bold color indicates the code meets the assumption

Table 6. Human Resources Management.

\begin{tabular}{lllll}
\hline \multirow{2}{*}{ CG code } & \multicolumn{2}{l}{ Conform with CG codes } & \multicolumn{2}{l}{ Not conform with CG codes } \\
\cline { 2 - 5 } & Yes & \% of Respondents & No & \% of Respondents \\
\hline Self-directed teams & 8 & 80 & 2 & 20 \\
Problem solving groups & 10 & 100 & 7 & 70 \\
Job rotation and cross training & 3 & 30 & 10 & 100 \\
Employee stock ownership plans & 7 & 70 & 3 & 30 \\
Profit sharing & 1 & 10 & 9 & 90 \\
Existence of trade union & & & & \\
\hline
\end{tabular}

Bold color indicates the code meets the assumption

\section{Abbreviation}

AGM: Annual General Meeting

ARCG: Asian Roundtable on Corporate Governance

BAS: Bangladesh Accounting Standard

CEO: Chief Executive Officer

CG: Corporate Governance

HRM: Human Resource Management

MBA: Masters of Business Administration

OECD: Organization for Economic Co-operation and Development

RJSC: Registrar of Joint Stock Company

SEC: Securities Exchange Commission

\section{References}

[1] Alam, K (2011), "Evaluation of Corporate Governance Practices by the Banking Sector of Bangladesh", A Research Study Report, Available at SOMBA Seminar Library, Khulna University, Khulna, pp. 3.

[2] Arun, T.G. and J. Turner (2003), "Corporate Governance of Banks in Developing Economies: Concepts and Issues", Corporate Governance: An International Review, Vol. 12, No. 3, pp. 371-377.

[3] Cadbury Committee, (1992), "Report of the Committee on the Financial Aspects of Corporate Governance", Gee
Publishing, London, U.K.

[4] Clarke, R. (1988), "Remarks in Comptroller of the Currency News Release", No. NR88-5, Washington DC.

[5] Douglas A. Lind, William G. Marchal, "Statistical Techniques in Business and Economics", Fourteenth Edition, pp. 146-147.

[6] Fama,E. and M. Jensen (1983), "Separation of Ownership and Control", Journal of Law and Economics, Vol. 26, pp. 301-325.

[7] Gupta, S. P. and M. P. Gupta (2006-2007), "Business Statistics", New Edition, Sultan Chand \& Sons, New Delhi, India, p. 506.

[8] Greuning, H. and S. Bratanovic (2003), "Analyzing and Managing Banking Risk: A Framework for Assessing Corporate Governance and Financial Risk", World Bank, Washington DC.

[9] Jensen, M.C. and Meckling, W.H. (1976), "Theory of the Firm Managerial Behavior, Agency Costs and Ownership Structure", Journal of Financial Economics, Vol. 3 No. 4, pp. 305-360.

[10] Kocourek, P. F, (2003), "Corporate Governance: Hard Facts about Soft Behaviors", Strategy \& Business, Issue 30, First Quarter.

[11] Mamtaz and Yusuf, (2005), "Corporate Governance: Bangladesh Perspective", The Cost and Management, Vol. 33 No. 6 November-December 2005, pp. 18-26. 
[12] Principles of corporate governance, OECD, 2004, OECD publications service, France
[13] W.G. Zikmund, (2010-2011), "Business Research Method", Eighth Edition, pp. 395-396. 